\title{
Valorization of Cellulose Recovered from WWTP Sludge to Added Value Levulinic Acid with a Brønsted Acidic Ionic Liquid
}

\author{
Katarzyna Glińska, Clara Lerigoleur, Jaume Giralt, Esther Torrens and Christophe Bengoa *D \\ Departament d'Enginyeria Química, Universitat Rovira i Virgili, Avinguda dels Països Catalans 26, \\ 43007 Tarragona, Spain; glinska88@gmail.com (K.G.); clara.lerigoleur@etu.univ-nantes.fr (C.L.); \\ jaume.giralt@urv.cat (J.G.); esther.torrens@urv.cat (E.T.) \\ * Correspondence: christophe.bengoa@urv.cat; Tel.: +34-977-559-619
}

Received: 21 August 2020; Accepted: 28 August 2020; Published: 2 September 2020

\begin{abstract}
The progressive decline of using fossil sources in the industry means that alternative resources must be found to produce chemicals. Waste biomass (sewage sludge) and waste lignocellulosic resources (food, forestry, or paper industries) are ideal candidates to take over from fossil sources. Municipal sewage sludge, and especially primary sludge, has a significant proportion of cellulose in its composition. Proper treatment of this cellulose allows the production of interesting chemicals like levulinic acid that are precursors (bio-blocks or building blocks) for other organic chemical processes. Cellulose was extracted from municipal wet primary sludge and paper industry dried sludge with a commercial ionic liquid. More than $99 \%$ of the cellulose has been recovered in both cases. Extraction was followed by the bleaching of the cellulose for its purification. In the bleaching, a large part of the ash was removed (up to 70\% with municipal sludge). Finally, the purified cellulose was converted in levulinic acid by catalyzed hydrothermal liquefaction. The reaction, done at $170{ }^{\circ} \mathrm{C}$ and 7 bar, catalyzed by a tailored Brønsted acidic ionic liquid produced levulinic acid and other by-products in smaller quantities. The process had a conversion of cellulose to levulinic acid of 0.25 with municipal sludge and of 0.31 with industrial sludge. These results fully justify the process but, require further study to increase the conversion of cellulose to levulinic acid.
\end{abstract}

Keywords: levulinic acid; hydrothermal liquefaction of cellulose; cellulose recovery and bleaching; paper industry sludge; municipal primary sludge; value-added chemicals; ionic liquid

\section{Introduction}

The fossil sources are non-renewable and, will be depleted in near future. According to International Energy Agency, coal reserves will be available up to 2112 while easy production of oil and gas will be spent by 2040 and 2042, respectively. Therefore, scientists are exploring how to produce chemicals from biomass sources in order to meet the human needs. There are 12 building blocks, or chemical platforms, essential molecules which can be converted to a wide range of chemicals or materials. These building blocks can be obtained from waste biomass without exposing supplies like food, feed, and forests and in general, biodiversity of the world. Moreover, the valorization of the waste biomass is beneficial from a point of view of sustainable waste management. Additionally, the valorization is economically attractive by eliminating waste disposal fees and giving value to wastes [1].

Building blocks are the basic components for organic chemistry. One of the building blocks is the levulinic acid (LA). LA is used as a building block for fuel additives, solvents, flavor substances, pharmaceutical agents, coating, dyes, rubber and plastic additives, and other industries [2,3]. The levulinic acid can be obtained from cellulose contained in biomass sources [4]. 
The production of levulinic acid from lignocellulosic material by conventional methods require the use of inorganic mineral acids (e.g., $\mathrm{H}_{2} \mathrm{SO}_{4}, \mathrm{HCl}, \mathrm{H}_{3} \mathrm{PO}_{4}$, and $\mathrm{HBr}$ ) and metal salts [5,6]. These catalytic combinations have the disadvantage of causing equipment corrosion, environmental problems, and difficulty with recyclability [7-9]. In turn, solid acid catalysts are an environmentally friendly replacement for liquid acid catalysts. They are recoverable and recyclable despite that the obtained yield is low and they need long reaction times [9,10]. Ionic liquids (ILs) are used as solvents to dissolve the cellulose. They can also be used as catalysts in the reaction to produce levulinic acid. In comparison with conventional methods, ILs are characterized by high thermal stability, low corrosive nature, easy recoverability, low vapor pressure and easy functionalization with high acidity [11]. In this study, ionic liquid with functional group $\left(-\mathrm{SO}_{3} \mathrm{H}\right)$ was used for the catalytic conversion of cellulose to levulinic acid. According to the literature [11], the catalytic activity of the functionalized ionic liquids decreased in the following order: $\mathrm{IL}_{-} \mathrm{SO}_{3} \mathrm{H}>\mathrm{IL}-\mathrm{COOH}>\mathrm{IL}-\mathrm{OH}$. Furthermore, the type of the cation has an effect on the acidity of IL. It is shown [12], that Brønsted acidic ILs with imidazolium-based cation has better catalytic activity than ammonium or triphenylphosphonium-based cations.

Figure 1 presents the mechanism of conversion of cellulose to levulinic acid. The mechanism involving several intermediates is explained below.
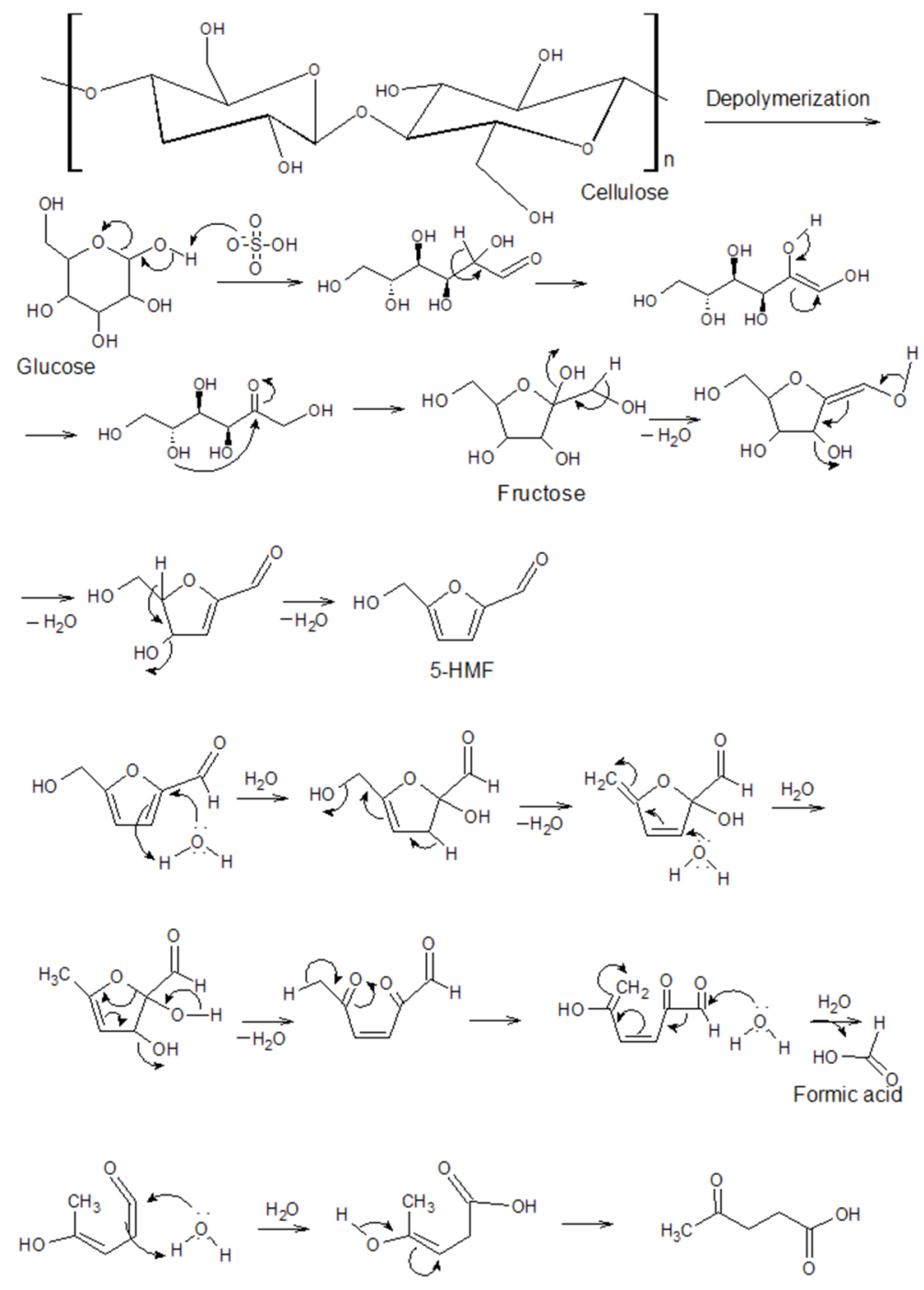

Levulinic acid

Figure 1. Mechanism of conversion of cellulose recovered from sludge to levulinic acid catalyzed by Brønsted acidic ionic liquid. Adapted from [13], copyright 2019, Elsevier. 
In the first step, the cellulose is depolymerized into the monomeric gluco-pyranose sub-units. The acidic group of IL (sulfonic acid) causes the formation of a carbonyl group by the opening of pyranose ring. The carbonyl group goes through the keto-enol equilibrium and generates the 1,2-enediol. Next, the 1,2-enediol via a ring closure reaction produces fructose. Then, the keto-enol isomerization of fructose gives the 5-hydroxymethylfurfural (5-HMF) and three molecules of water are eliminated [13]. During the rehydration reaction of 5-HMF, levulinic acid is formed while a parallel reaction is forming a by-product: insoluble polymeric humins $[3,14]$. Humins are insoluble macromolecular components remained after carbohydrates catalysis. They can be used as composite material, building blocks, or soil amendment [15-17].

According to the literature [18], during the catalytic conversion of cellulose to levulinic acid, 5-HMF is obtained as by-product and, its concentration increases at reaction temperatures above $200{ }^{\circ} \mathrm{C}$. Other by-products that can be obtained are furfural, formic acid and acetic acid. Due to the hydrolysis of hemicellulose to xylose followed by its dehydration allows the formation of furfural. A further dissociation of furfural let to obtain formic acid and acetic acid [19].

So far, in our view, only two papers have been published related to the production of levulinic acid from sludge or residual biomass from the paper industry [20,21]. In the first work, paper mill sludge was obtained from a packaging company and converted by hydrothermal liquefaction catalyzed by hydrochloric acid. Tests were also carried out with a microwave reactor. The conversion in levulinic acid obtained have approached $80 \%$ of the theoretical [20]. In the second work, fiber sludge from Finnish and Swedish pulp industry has been used. In this case, a microwave reactor was used, the reaction being catalyzed by Bronsted and Lewis acids. In this case, the conversion has not exceeded $35 \%$ with respect to the theoretical [21].

There are three main objectives in this work: (i) recovery of cellulose from waste biomass: municipal wastewater treatment plant (WWTP) primary wet sludge and paper industry dried mixed sludge, from primary treatment and membrane bioreactor purge. This first part was done using well-known methodology from previous studies [22-24]; (ii) the recovered cellulose from both type of sludges was purified by a bleaching procedure to decrease the amount of proteins and ashes in the solid phase after extraction; and (iii) the extracted and purified cellulose was converted to levulinic acid, value-added chemical considered as building-block by chemical industry. Hydrothermal liquefaction catalyzed by Brønsted acidic ionic liquid was used to produce the levulinic acid.

To the best of our knowledge, this is the first time that: (i) cellulose was recovered from municipal and industrial sludge by extraction with commercial ionic liquids; (ii) the recovered cellulose was bleached in two steps; and (iii) the purified cellulose was converted in levulinic acid by hydrothermal treatment catalyzed by home-made ionic liquid, all processes done consecutively.

\section{Results and Discussion}

Figure 2 presents the overall scheme of the process of production of levulinic acid from cellulose. In a first step, the cellulose is recovered from WWTP primary wet sludge and paper industry dried mixed sludge, from primary treatment and membrane bioreactor purge. The extraction was realized with Tetrakis ionic liquid [22-24]. In a second step, the recovered cellulose was bleached through two consecutives treatments with hydrogen peroxide and hydrochloric acid. Finally, purified cellulose was treated by catalyzed hydrothermal liquefaction to produce levulinic acid. Figure 2 also shows all the procedures of separation of products and their characterization after the overall process. 


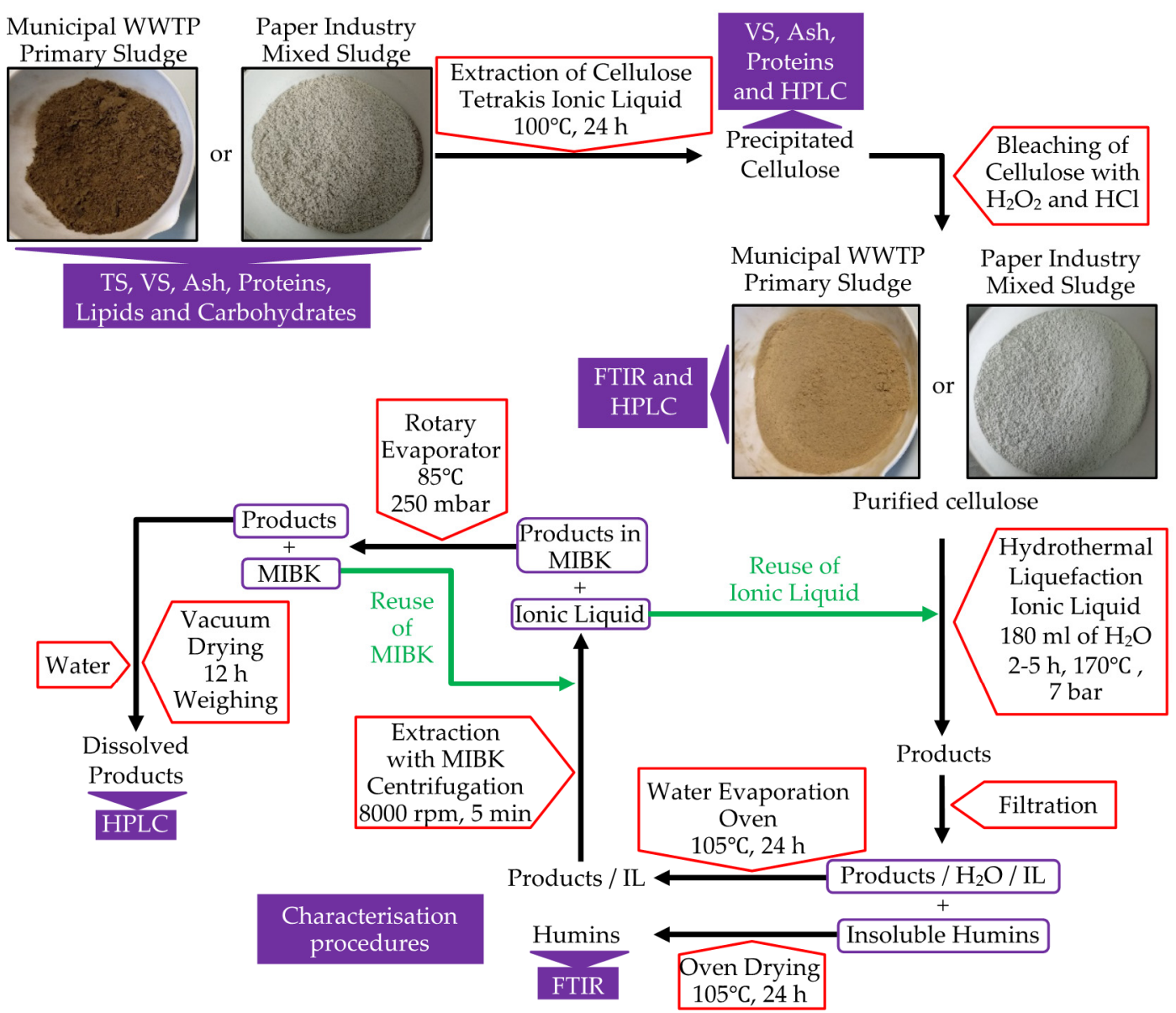

Figure 2. Scheme of full process of conversion of cellulose recovered from sludge to levulinic acid catalyzed by Brønsted acidic ionic liquid.

\subsection{Characterization of Sludge}

Primary sludge was collected from the municipal WWTP of Reus (Tarragona, Spain). The WWTP has a capacity to daily process $25,000 \mathrm{~m}^{3}$ of wastewater. Primary sludge was collected after the partial gravity thickening, located later the primary decanter. The industrial sludge was provided by the international paper company Gomà-Camps, S.A., situated in La Riba (Tarragona, Spain). This sludge is a mixed sludge from physical-chemical primary treatment and purge of membrane biological reactor. Both effluents are mixed and dried with hot air. The results of the characterization of both sludges are presented in Table 1.

Table 1. Characterization of municipal primary sludge and industrial paper sludge by conventional procedures.

\begin{tabular}{ccc}
\hline & Municipal Primary Sludge & Industrial Paper Sludge \\
\hline TS $\left(\%, w / w_{\text {wet sludge }}\right)$ & $3.8 \pm 0.1$ & $46.9 \pm 1.1$ \\
Moisture $\left(\%, w / w_{\text {wet sludge }}\right) *$ & $96.2 \pm 0.1$ & $53.1 \pm 1.1$ \\
Ashes $\left(\%, w / w_{\mathrm{TS}}\right)$ & $23.5 \pm 2.3$ & $50.5 \pm 0.2$ \\
VS $\left(\%, w / w_{\mathrm{TS}}\right)$ & $76.5 \pm 1.7$ & $49.5 \pm 0.2$ \\
Lipids $\left(\%, w / w_{\mathrm{TS}}\right)$ & $22.9 \pm 1.8$ & $1.2 \pm 0.1$ \\
Proteins $\left(\%, w / w_{\mathrm{TS}}\right)$ & $28.2 \pm 1.5$ & $5.3 \pm 0.1$ \\
Carbohydrates $\left(\%, w / w_{\mathrm{TS}}\right)$ & $25.8 \pm 1.9$ & $42.6 \pm 0.7$ \\
Total $\left(\%, w / w_{\mathrm{TS}}\right)$ & $100.4 \pm 7.5$ & $99.6 \pm 0.9$ \\
\hline
\end{tabular}

Values are mean, $\pm \mathrm{SD}, n=3 .{ }^{*}$ By difference. 
As received, both sludges differ a lot, municipal WWTP primary sludge, henceforth municipal sludge, is essentially a liquid with solids in suspension. On the other hand, paper industry dried sludge, henceforth industrial sludge, is a solid. This difference is essentially due to the water content of each sludge.

As it can be seen in the table, the moisture of municipal sludge reaches $96.2 \%$, whereas in industrial sludge this value is almost half-lower: $53.1 \%$. Then, the total solids are $3.8 \%$ and $46.9 \%$ for municipal sludge and industrial sludge, respectively. After drying, both sludges also differ in their composition. Municipal sludge is constituted by more or less $25 \% w / w_{\mathrm{TS}}$ of inorganic ashes and $25 \% w / w_{\mathrm{TS}}$ of each organic matter: lipids, carbohydrates, and proteins. This composition has been quite constant during the last years as it can be seen comparing other works [22,25] and now. In contrast, industrial sludge is mainly constituted by ashes $\left(50.5 \% w / w_{\mathrm{TS}}\right)$ and carbohydrates $\left(42.3 \% w / w_{\mathrm{TS}}\right)$. The rest of the organic substances of the industrial sludge represent a low proportion: lipids $\left(1.2 \% w / w_{\mathrm{TS}}\right)$ and proteins $\left(5.0 \% w / w_{\mathrm{TS}}\right)$. This composition is similar than the observed in a recent work of the authors [24].

\subsection{Extraction of Cellulose from Both Municipal and Industrial Sludges with IL}

The process of recovery of cellulose from municipal and industrial sludges was performed using a similar method presented elsewhere [22-24]. Tetrakis ionic liquid was used to extract the cellulose. The temperature of process was fixed at $100^{\circ} \mathrm{C}$ and the extraction was performed during $24 \mathrm{~h}$. These values were optimized in the past [22-24]. Then methanol was added to the mixture to precipitate the cellulose. Three phases were obtained: (i) organic phase in the top of the flask; (ii) intermediate light brown aqueous phase containing ionic liquid, water, methanol, part of the proteins, and part of the ashes; and (iii) precipitated brown phase containing all cellulose and the rest of proteins and ashes. Then, hexane is added to the mixture to dissolve the organic phase and, is separated with a pipette. The operation was repeated until the organic phase is transparent. The aqueous phase and the precipitate were separated by centrifugation, $3500 \mathrm{rpm}$ for $10 \mathrm{~min}$. The precipitate containing cellulose and part of the proteins and ashes was separated by centrifugation at $6000 \mathrm{rpm}$ during $10 \mathrm{~min}$. The precipitate was cleaned with methanol and centrifuged again in the same conditions. Then the precipitate was characterized.

\subsection{Characterization of the Solid Products after the Process of Recovery with IL}

Table 2 presents the characterization of the solid products after the process of recovery of cellulose from both sludges. As it was expected, taking into account experimental errors, the process of recovery with Tetrakis IL was able to recover almost all carbohydrates from both sludges. However, besides of carbohydrates, the solids still contain a part of ashes and proteins.

Table 2. Characterization of the precipitates after the recovery of cellulose $\left(100^{\circ} \mathrm{C}, 24-\mathrm{h}\right)$.

\begin{tabular}{ccc}
\hline Composition $\left(\%, w / w_{\text {TS }}\right)$ & Municipal Sludge & Industrial Sludge \\
\hline Proteins & $8.9 \pm 1.9$ & $4.1 \pm 0.7$ \\
Ashes & $16.2 \pm 2.5$ & $33.6 \pm 0.5$ \\
Carbohydrates & $28.7 \pm 5.3$ & $43.5 \pm 1.3$ \\
Total & $53.8 \pm 9.7$ & $81.2 \pm 2.5$ \\
\hline
\end{tabular}

Values are mean, $\pm \mathrm{SD}, n=3$.

On the contrary, lipids were totally removed during the separation. With municipal sludge, the process was able to decrease the quantity of ashes from 23.5 to $16.2 \% w / w_{\mathrm{TS}}$ and the quantity of proteins from 28.4 to $8.9 \% w / w_{\text {TS }}$. In the case of the industrial sludge, the drop-in values were from 50.5 to $33.6 \% w / w_{\mathrm{TS}}$ and from 5.0 to $4.1 \% w / w_{\mathrm{TS}}$ for ashes and proteins, respectively. The presence of ashes and proteins in the solid products required the need to clean them to purify the cellulose. 


\subsection{Bleaching of Precipitate}

The procedure of the bleaching of recovered precipitate was based on the literature [26,27]. According to these works, hydrogen peroxide is commonly used as a bleaching agent responsible for lignin dissolution. In the first step of the process, a dried batch of recovered precipitate from municipal or industrial sludge was mixed with a solution of hydrogen peroxide $\left(\mathrm{H}_{2} \mathrm{O}_{2}\right) 8 \%$ for the dissolution of lignin and protein. The mixture was stirred $24 \mathrm{~h}$ at room temperature. Then, the mixture was filtered. The precipitate was cleaned with distillate water. The content of protein and ashes were determined in both precipitates. The results of the bleaching process are presented in Table 3.

Table 3. Characterization of the precipitates after bleaching $\left(8 \% \mathrm{H}_{2} \mathrm{O}_{2}\right.$ and $\left.0.1 \mathrm{~N} \mathrm{HCl}\right)$.

\begin{tabular}{ccc}
\hline Composition $\left(\%, w / w_{\text {TS }}\right)$ & Municipal Sludge & Industrial Sludge \\
\hline Proteins* & $6.4 \pm 1.6(-28 \%)$ & $1.8 \pm 0.4(-56 \%)$ \\
Ashes $* *$ & $4.9 \pm 1.8(-70 \%)$ & $21.5 \pm 0.3(-36 \%)$ \\
Carbohydrates & $24.4 \pm 7.0(-15 \%)$ & $38.3 \pm 3.7(-12 \%)$ \\
Total & $35.7 \pm 10.4(-34 \%)$ & $61.6 \pm 4.4(-24 \%)$ \\
\hline
\end{tabular}

Values are mean, $\pm \mathrm{SD}, n=3 .{ }^{*}$ Quantified after hydrogen peroxide treatment. ${ }^{* *}$ Quantified after hydrochloric acid treatment. In brackets: rate of reduction.

Proteins were determined after $\mathrm{H}_{2} \mathrm{O}_{2}$ treatment. As it can be seen in the table, the $\mathrm{H}_{2} \mathrm{O}_{2}$ solution was able to dissolve and remove $28 \%$ and $56 \%$ of protein from municipal and industrial precipitates, respectively. Proteins dissolution in $\mathrm{H}_{2} \mathrm{O}_{2}$ can be explained by the dissociation of $\mathrm{H}_{2} \mathrm{O}_{2}$ to hydrogen $\left(\mathrm{H}^{+}\right)$and hydroxyl $\left(\mathrm{OH}^{-}\right)$radicals. Then, these oxidative agents readily attacked proteins and decomposed them into soluble amino acids [28]. However, $\mathrm{H}_{2} \mathrm{O}_{2}$ did not reduce the quantity of ashes from the precipitate, acid hydrolysis with $0.1 \mathrm{~N} \mathrm{HCl}$ is expected to do that.

In the second step, both precipitates were hydrolyzed with hydrochloric acid $(\mathrm{HCl}) 0.1 \mathrm{~N}$ during $5 \mathrm{~h}$ in an ultrasonic bath. The initial transparent acid dissolution changed color to light brown/yellow. After separation, cleaning and drying of precipitate, ashes were quantified. The acidic treatment was able to remove $70 \%$ and $36 \%$ of the ashes from municipal and industrial precipitates, respectively. It is noticeable that during the bleaching treatment a loose of carbohydrates was also observed, $15 \%$ and $12 \%$ from municipal and industrial precipitates, respectively. According to the literature [26], the hydrolysis also makes isolation of the pure cellulose fibers by hydrolyzing traces of hemicellulose and lignin to simple sugars. In Table 4 are presented the results of high-performance liquid chromatography (HPLC) analysis of precipitates before and after bleaching. It can be seen in the table that the amount of hemicellulose and lignin reduced after bleaching. However, the amount of cellulose increased for both sludges, more in the case of the industrial sludge, from 32.8 to $42.3 \%$. This increasing can be explained by the growth of the amount of simple sugars, such as glucose, provoked by the treatment with $\mathrm{HCl}$. As the measure of cellulose is obtained from the values of glucose [29], the results show an increasing amount of cellulose.

Table 4. Characterization of the carbohydrates by high-performance liquid chromatography (HPLC) after bleaching $\left(8 \% \mathrm{H}_{2} \mathrm{O}_{2}\right.$ and $\left.0.1 \mathrm{~N} \mathrm{HCl}\right)$.

\begin{tabular}{ccccc}
\hline Carbohydrates & \multicolumn{2}{c}{ Municipal Sludge } & \multicolumn{2}{c}{ Industrial Sludge } \\
$\left(\boldsymbol{\%}, \boldsymbol{w} / \boldsymbol{w}_{\text {precipitate }}\right)$ & Before Bleaching & After Bleaching & Before Bleaching & After Bleaching \\
\hline Hemicellulose & $7.7 \pm 1.0$ & $3.4 \pm 0.1$ & $7.2 \pm 0.1$ & $6.5 \pm 0.0$ \\
Cellulose * & $25.3 \pm 0.6$ & $26.7 \pm 3.2$ & $32.8 \pm 1.3$ & $42.3 \pm 0.9$ \\
Lignin & $20.0 \pm 3.0$ & $17.7 \pm 0.3$ & $10.9 \pm 2.3$ & $10.2 \pm 0.3$ \\
\hline
\end{tabular}

Values are mean, $\pm \mathrm{SD}, n=3 .{ }^{*}$ Amount of cellulose calculated by division of the amount of glucose by a conversion factor of 1.11 [29].

Figure 3 presents Fourier Transform Infrared (FTIR) spectra of purified cellulose recovered from municipal sludge (a) and industrial sludge (b). Both spectra present some characteristic absorbances 
in different frequency regions: $3300 \mathrm{~cm}^{-1}$ of $\mathrm{O}-\mathrm{H}$ group, $2900 \mathrm{~cm}^{-1}$ assigned as the $\mathrm{CH}_{3}$ and $\mathrm{CH}_{2}$ stretching vibration of cellulose, $1160 \mathrm{~cm}^{-1}$ of $\mathrm{C}-\mathrm{O}-\mathrm{C}$ stretching vibration particularly associated with cellulose and the broad peak $1030 \mathrm{~cm}^{-1}$ of $\mathrm{C}-\mathrm{O}$ stretching vibration of carbohydrates. All of those peaks demonstrate that purified solids contain cellulose. In Figure $3 \mathrm{a}$ there is also presented the peak at $1650 \mathrm{~cm}^{-1}$ associated to peptide amide groups of proteins while in Figure $3 \mathrm{~b}$, is absent. That confirms that after bleaching some part of proteins $(6.8 \%)$ stay in the cellulose recovered from municipal sludge whereas the amount of proteins in the purified cellulose recovered from industrial sludge is too small $(1.8 \%)$ to be visible in the spectra.
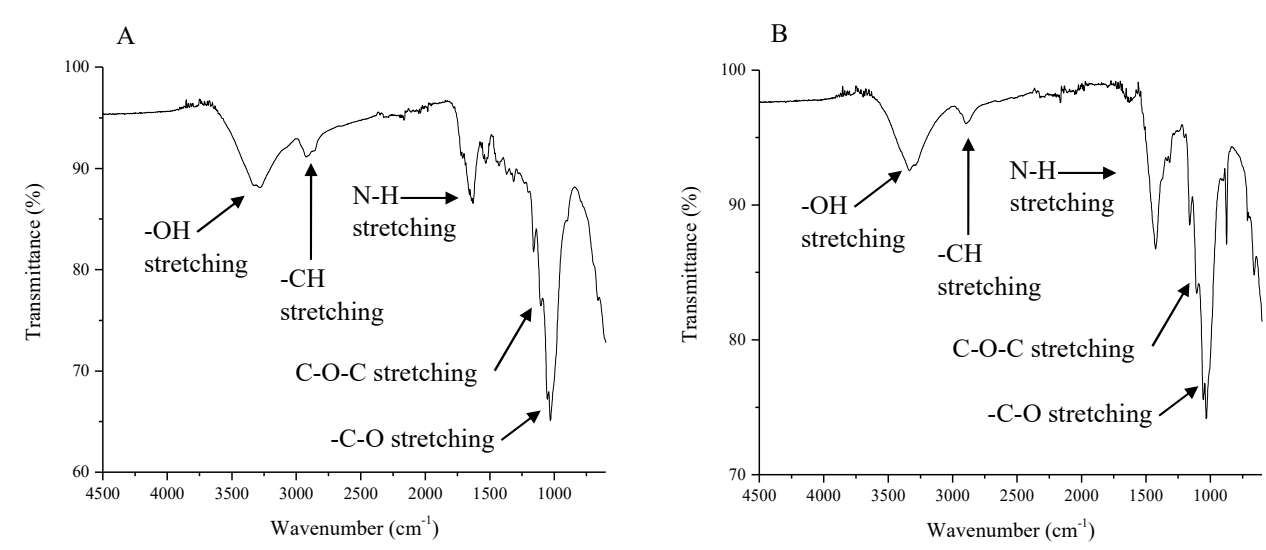

Figure 3. Fourier Transform Infrared (FTIR) spectra of purified cellulose after extraction with ionic liquid and bleaching with $\mathrm{H}_{2} \mathrm{O}_{2}$ and $\mathrm{H}_{2} \mathrm{SO}_{4}$ : (A) municipal sludge and (B) industrial sludge.

\subsection{Cellulose Conversion to Levulinic Acid}

The procedure of conversion of cellulose to levulinic acid catalyzed by Brønsted acidic ionic liquid was directly based on a recent work [3]. In this work, authors have synthesized and tested nine different ionic liquids. The results showed that the acidity of the ionic liquid has the greater importance on the yield of the reaction. The acidity depends on the cation group and on the anion. The $\left[\mathrm{mimC}_{4} \mathrm{SO}_{3} \mathrm{H}\right]$ $\left[\mathrm{HSO}_{4}\right]$ ionic liquid has the higher acidity resulting in its design by the presence of the imidazolium group and by the hydrogen sulfate anion [3]. In consequence, $\left[\mathrm{mimC}_{4} \mathrm{SO}_{3} \mathrm{H}\right]\left[\mathrm{HSO}_{4}\right]$ was selected and synthesized to convert cellulose to levulinic acid by catalyzed hydrothermal liquefaction.

After the reaction, the reactor was cleaned with deionized water and the products were separated and characterized. The first separation was realized by filtration. Residual solids were abundantly washed with deionized water, dried and weighed. The liquid phase is a mixture of water, ionic liquid and products. Water was evaporated overnight in an oven. Then, the ionic liquid was separated from the resulting liquid mixture by addition of methyl isobutyl ketone (MIBK). Two liquid phases were formed, the upper phase contain the levulinic acid dissolved in the MIBK while the lower phase the ionic liquid. Both phases were separated by centrifugation at $8000 \mathrm{rpm}$ for $5 \mathrm{~min}$. MIBK was evaporated from organic phase at the rotary evaporator at $85^{\circ} \mathrm{C}$ and 250 mbar. Resultant products were dried under vacuum and weighed. Finally, products were characterized by HPLC. In Table 5 are presented the values of the weight of biomass, weight of cellulose contained in the biomass, weight of ionic liquid, and volume of water used in each reaction. Table 5 also presents the values of weight of soluble in MIBK products, weight and percentage of levulinic acid and finally weight and percentage of humins. 
Table 5. Weight of products, levulinic acid and humins after hydrothermal treatment of cellulose with acidic ionic liquid (temperature: $170{ }^{\circ} \mathrm{C}$, time of reaction: $5 \mathrm{~h}$ ).

\begin{tabular}{|c|c|c|c|c|c|c|c|c|c|c|}
\hline \multirow[t]{2}{*}{$\mathbf{N}^{\circ}$} & \multirow{2}{*}{ Source } & \multirow{2}{*}{$\begin{array}{l}\text { Biomass } \\
\text { (g) }\end{array}$} & \multirow{2}{*}{$\begin{array}{l}\text { Cellulose } \\
\text { (g) }\end{array}$} & \multirow{2}{*}{ IL (g) } & \multirow{2}{*}{$\begin{array}{l}\mathrm{H}_{2} \mathrm{O} \\
(\mathrm{mL})\end{array}$} & \multirow{2}{*}{$\begin{array}{l}\text { Products } \\
\text { (g) }\end{array}$} & \multicolumn{2}{|c|}{$\begin{array}{l}\text { Levulinic } \\
\text { Acid }\end{array}$} & \multicolumn{2}{|c|}{ Humins } \\
\hline & & & & & & & (g) & $(\%)$ & (g) & $(\%)$ \\
\hline 1 & Sigmacell (2 h) & - & 4.8 & 30.0 & 180 & 0.9 & 0.9 & 18.8 & 3.2 & 66.7 \\
\hline 2 & Sigmacell & - & 4.5 & 30.0 & 180 & 2.7 & 2.6 & 57.8 & 0.9 & 20.0 \\
\hline 3 & Sigmacell & - & 16.0 & 30.0 & 180 & 13.1 & 13.0 & 81.3 & 3.0 & 18.8 \\
\hline 4 & IS Purified & 6.7 & 2.8 & 26.6 & 180 & 0.4 & 0.2 & 7.1 & 5.9 & 88.1 \\
\hline 5 & IS Purified & 8.9 & 3.8 & 26.6 & 180 & 0.6 & 0.4 & 10.5 & 8.3 & 93.3 \\
\hline 6 & IS Purified & 9.8 & 4.2 & 30.0 & 180 & 1.4 & 1.3 & 31.0 & 8.8 & 89.8 \\
\hline 7 & IS Purified & 8.9 & 3.8 & 36.0 & 180 & 0.7 & 0.7 & 18.4 & 7.6 & 84.4 \\
\hline 8 & MS Purified & 8.2 & 2.2 & 26.0 & 180 & 0.6 & 0.5 & 22.7 & 6.8 & 82.9 \\
\hline 9 & MS Purified & 19.9 & 5.3 & 36.0 & 180 & 0.7 & 0.6 & 11.3 & 14.2 & 71.4 \\
\hline 10 & MS Purified & 8.9 & 2.4 & 26.0 & 180 & 0.7 & 0.6 & 25.0 & 8.0 & 89.9 \\
\hline 11 & IS & 12.1 & 4.1 & 26.0 & 180 & 0.01 & 0.01 & 0.2 & 10.2 & 84.3 \\
\hline 12 & MSar & 200.9 & 1.0 & 6.0 & 0 & 0.03 & 0.02 & 2.0 & 6.8 & 89.5 \\
\hline
\end{tabular}

IL: Ionic Liquid; IS: Industrial Sludge (as received); MS: Municipal Sludge; MSar: Municipal Sludge (as received, wet, TS: $3.8 \% w / w_{\text {wet sludge) }}$.

As it was expected, levulinic acid was obtained in each reaction with the three sources of cellulose: pure from provider, from municipal and from industrial sludge. About the commercial cellulose, entries 1-3, it can be observed that with a reaction time of only $2 \mathrm{~h}$, the conversion to levulinic acid was only $18.8 \%$. Increasing the reaction time to $5 \mathrm{~h}$ allowed a conversion of $57.8 \%$. This is normal, increasing the reaction time produces an increase in the conversion. However, this increase in conversion reaches a maximum and then decreases, due to the appearance of condensation and recombination reactions of the products. Then, it will be necessary in a future work to confirm this fact, because it is possible that optimized time of reaction was not attained. On the other hand, the decrease of the ratio between the weight of the ionic liquid and the weight of cellulose in the sample, $\mathrm{w}_{\mathrm{IL}} / \mathrm{w}_{\text {Cellulose }}$ : from 6.67 to 1.88 , allowed to increase the conversion to levulinic acid until $81.3 \%$. The effect of the ratio $\mathrm{w}_{\text {IL }} / \mathrm{w}_{\text {Cellulose }}$ on the conversion to levulinic acid seems to be important. This will be studied in more detail in further work.

The results of conversion to levulinic acid obtained with industrial sludge are less good (entries 4-7). In the four experiments carried out, the conversion to levulinic acid was between 7.1 and $31.0 \%$. The reduction of the conversion is normal since in the samples of industrial sludge there is presence of hemicellulose, lignin, ash and other materials that disturb the reaction of conversion of the cellulose. As it was the case with commercial cellulose (Sigmacell), the decrease in the ratio $\mathrm{w}_{\mathrm{IL}} / \mathrm{w}_{\text {Cellulose }}$ causes an increase in the conversion to levulinic acid. Indeed, in entries 4 and 7 the ratio is 9.5 and the conversions are 7.1 and $18.4 \%$, respectively. In entries 5 and 6 the ratio is 7.0 and conversions are 10.5 and $31.0 \%$, respectively. However, there is a disparity between the results obtained with the same ratio. There is another variable that seems to be important: the water to cellulose ratio, $\mathrm{w}_{\text {Water }} / \mathrm{w}_{\text {Cellulose }}$. Indeed, in entries 4 and 7 the $w_{\text {Water }} / w_{\text {Cellulose }}$ ratios were 64.3 and 47.4 , respectively. On the other hand, in entries 5 and 6 the $\mathrm{w}_{\text {Water }} / \mathrm{w}_{\text {Cellulose }}$ ratios were 47.4 and 42.9 , respectively. The decrease in the $\mathrm{w}_{\text {Water }} / \mathrm{w}_{\text {Cellulose }}$ ratio causes a consequent increase in the conversion to levulinic acid. These trends will have to be confirmed in subsequent work.

In the case of municipal sludge, entries 8-10, the results of conversion to levulinic acid were quite similar: between 11.3 and $25.0 \%$. Again, impurities in the samples were responsible of the decrease of the conversion to levulinic acid. However, with municipal sludge, the decrease in the ratio $\mathrm{w}_{\text {IL }} / \mathrm{w}_{\text {Cellulose }}$ does not seem to present a clear trend. Indeed, in entries 8,10 , and 9 , the $\mathrm{w}_{\text {IL }} / \mathrm{w}_{\text {Cellulose }}$ ratios are $11.8,10.8$, and 6.8 , respectively, while the conversions to levulinic acid are 22.7, 25.0, and $11.3 \%$ respectively. It can be seen that between entries 8 and 10 there is an increase in the conversion but, then, it decreases sharply. The effect of the $\mathrm{w}_{\text {Water }} / \mathrm{w}_{\text {Cellulose }}$ ratio on the conversion was the same. 
In entries 8,10 , and 9 , the $\mathrm{w}_{\text {Water }} / \mathrm{w}_{\text {Cellulose }}$ ratios are $81.8,75.0$, and 34.0 , respectively. The explanation for this negative result must be sought in the design of the experiment. Indeed, the experiment in entry 9 was carried out with a mass of sludge of almost $20 \mathrm{~g}$, while in experiments 8 and 10 this mass was between 8 and $9 \mathrm{~g}$. While the amount of cellulose available is higher, the amount of impurities even more. This must have disturbed the cellulose conversion reaction and maybe the mixing into the reactor. On the other hand, observing the mass balances of these experiments it can be seen that the balance for entry 9 was only $75 \%$, while the mass balances for entries 8 and 10 were 90 and $98 \%$, respectively. This fact could explain the bad result obtained with the experiment in entry 9.

The experiments realized with industrial and municipal sludge as received, entries 11 and 12 respectively, gave even smaller conversions to levulinic acid: 0.2 and $2.0 \%$, respectively. The cause of this great decrease can be found in the fact that both sludges contain large amounts of ashes, 23.5 and $50.5 \%$, respectively.

As it can be seen in Table 5, levulinic acid represents more of the $90 \%$ of the total products. The other products are lactic acid, formic acid, HMF, and furfural. These other products were also found elsewhere [3]. In Figure 4, two chromatograms from HPLC analysis of products obtained from hydrothermal processing of cellulose are presented from industrial sludge (a) and municipal sludge (b).

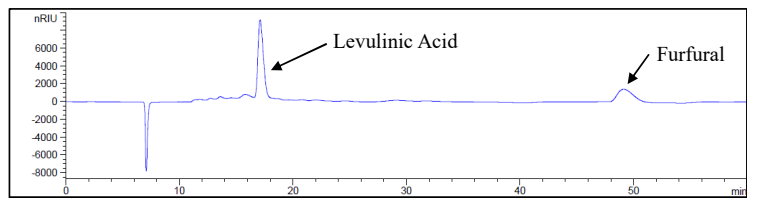

(a)

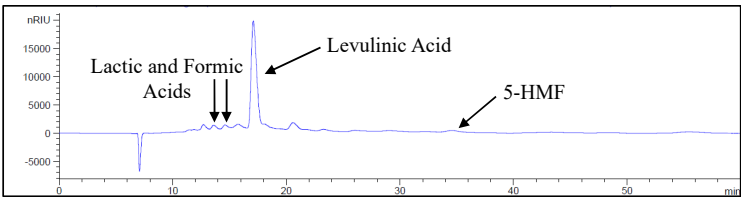

(b)

Figure 4. Chromatograms of products obtained from catalyzed hydrothermal liquefaction of cellulose with acidic ionic liquid: (a) industrial sludge and (b) municipal sludge.

In both chromatograms it is clearly showed that the higher peak (retention time $17.1 \mathrm{~min}$ ) corresponds to levulinic acid. The other small peaks are the co-products identified in laboratory: furfural, lactic acid, formic acid, and 5-hydroxymethylfurfural (5-HMF). Further analysis of the products by LC-MS allowed to identify more substances in the products. Table 6 presents the list of substances detected by LC-MS, the retention time of each compound and molecular mass of positive and negative ion electrospray analysis.

Table 6. Products identified by LC-MS after hydrothermal treatment.

\begin{tabular}{ccccc}
\hline Entry & Retention Time (min) & $\mathbf{m} / \mathbf{z}+$ & $\mathbf{m} / \mathbf{z}-$ & Compound \\
\hline 1 & 8.093 & 117.0188 & 115.0031 & Fumaric Acid \\
2 & 10.709 & 135.0293 & 133.0137 & Malic Acid \\
3 & 11.625 & 181.0712 & N.D. & Mannose \\
4 & 11.653 & N.D. & 179.0556 & Glucose \\
5 & 13.558 & 91.0395 & 89.0239 & Lactic Acid \\
6 & 13.791 & 119.0344 & 117.0188 & Succinic Acid \\
7 & 13.924 & 93.0552 & 91.0395 & Glycerol \\
8 & 14.491 & 97.0290 & 95.0133 & Furfural \\
9 & 14.602 & 175.0243 & 173.0086 & cis-Aconitic Acid \\
10 & $14.849 *$ & N.D. & 59.0133 & Acetic Acid \\
11 & 16.124 & 111.0421 & 87.0446 & Butyric Acid \\
12 & 19.473 & 117.0552 & 115.0395 & Levulinic Acid \\
13 & 23.863 & 151.0243 & 149.0086 & Tartaric Acid \\
14 & 43.633 & 127.0395 & 125.0239 & 5-HMF \\
\hline
\end{tabular}

N.D. not detected. * Only detected in products obtained from municipal sludge. 
All compounds, except acetic acid, were detected in the products obtained from both types of sludge. Acetic acid was only presented in products obtained from municipal sludge. Almost all compounds are short-chain organic acid. These are the expected products of hydrolysis of the cellulose [30]. Apart from organic acids, products of conversion of both sludges contain also glucose, furfural, and 5-HMF.

The peak of furfural has appeared in the chromatogram of conversion products of industrial sludge, Figure $4 \mathrm{a}$, but not in that of municipal sludge, Figure $4 \mathrm{~b}$. LC-MS analysis confirmed the peak of furfural in both cases. Furfural comes from the dehydration of xylose. On the other hand, xylose makes up most of the hemicellulose. In Table 4, it could be observed that the hemicellulose content in industrial sludge is double that in municipal sludge. For this reason, the furfural peak is observed in the chromatogram of industrial sludge and not in that of municipal sludge. In the case of 5-HMF, the conversion reactions were carried out at temperatures below $200{ }^{\circ} \mathrm{C}$ and therefore large amounts of 5-HMF were not produced. A 5-HMF peak cannot be seen in the chromatogram of conversion products of industrial sludge, Figure 4a. However, in the chromatogram of conversion products of the municipal sludge, Figure $4 \mathrm{~b}$, a very small one appears, as a result of which the 5-HMF was not completely dehydrated to levulinic acid.

On the other hand, Table 5 also presents the weights and the yields of residual solids. Calculation was made based on the weight of biomass used in each reaction. The residual solids were in water insoluble dark-brown solids. The solids after filtration were abundantly washed with water to eliminate the remaining ionic liquid. Then, they were dried and weighted. As it can be seen in the table, depending on the source of cellulose used for the reaction of conversion to levulinic acid, the obtained yield of humins differ. Commercial cellulose (Sigmacell) obtained conversions to humins of $\sim 20 \%$ except in the case of the experiment carried out for two hours, where the conversion reached was $66 \%$. This increment was caused by insufficient the time to convert cellulose to products. In the case of all the other experiments, purified celluloses from municipal and industrial sludges, or from both sludges used as received, the conversions to humins were higher and quite similar, between 80 and $90 \%$. The yields of residual wastes formed during the reactions with cellulose from sludges was due to the content of ash and proteins in municipal and industrial sludge. After cellulose extraction and purification, a part of ashes and proteins still remained in the cellulose. Subsequently, during the reaction, those organic and inorganic matters pass to the solid residue, at the same time, increasing the yield of humins. Figure 5 shows the FTIR spectra of humins obtained after reaction of purified cellulose from both sludges.
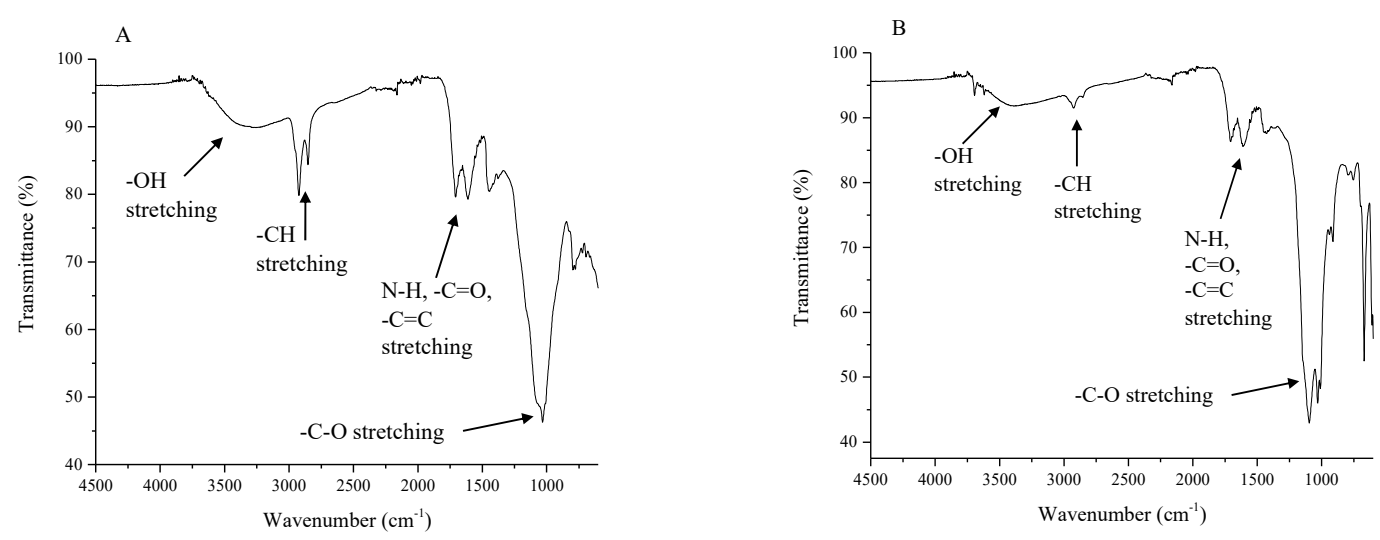

Figure 5. FTIR spectrum of humins obtained from hydrothermal processing of cellulose with acidic ionic liquid: (A) municipal primary sludge and (B) industrial sludge.

In both spectra, it can be observed some characteristic absorbances in different frequency regions. The peak at $3400 \mathrm{~cm}^{-1}$ is associated with hydroxyl group stretching vibrational bands. The peaks at 2950 $\mathrm{cm}^{-1}$ and $1000-1250 \mathrm{~cm}^{-1}$ are attributed to $-\mathrm{CH}$ and $-\mathrm{CO}$ stretching vibrations, respectively. It is also 
possible to observe strong peaks at 1700 and $1625 \mathrm{~cm}^{-1}$, corresponding to carbonyl group conjugated to an alkene group. This is because carbohydrates are converted into humins according to the reaction pathway: cellulose $\rightarrow$ 5-HMF $\rightarrow$ 2,5-dioxo-6-hydroxyhexanal $\rightarrow$ humins [14,31]. Although, the peak at $1625 \mathrm{~cm}^{-1}$ is also associated with peptide amide groups of proteins. The FTIR spectra confirm that except humins, ashes, proteins and part of unreacted cellulose goes to insoluble solids.

To summarize, the full process of production (extraction, bleaching, and catalyzed hydrothermal liquefaction) of levulinic acid from municipal or paper industry has been a success. It is true that the conversions obtained are not high, but it must be taken into account that the entire study is in fact a technological feasibility study. A scale-up of the process can only be carried out when some aspects of the process units will have been solved: (i) optimizing the extraction of cellulose from both sludges through an improved design of the ionic liquid; (ii) improve the cleaning of the cellulose after its extraction, although if more severe methods are used, a greater part of it can be hydrolyzed; and (iii) optimize the reaction operations in the conversion of cellulose to levulinic acid, reaction time and temperature, cellulose/ionic liquid/water ratios, or improvement in the design of the ionic liquid.

\section{Materials and Methods}

\subsection{Reagents}

All chemical reagents used in this work were supplied by Sigma-Aldrich (Barcelona, Spain). Tetrakis (hydroxymethyl) phosphonium chloride $\left(\mathrm{P}\left(\mathrm{CH}_{2} \mathrm{OH}\right)_{4}\right] \mathrm{Cl}$, hydrated ionic liquid, $80 \%$ in water, ref: 404861) was used to recover the cellulose from municipal primary sludge and from industrial sludge. Hydrogen peroxide solution ( $\geq 30 \%$ ref: 95321 ) and $0.1 \mathrm{~N}$ hydrochloric acid solution (ref: 2104) were applied to purify recovered cellulose. 1-methylimidazole (purity $\geq 99 \%$, ref: 336092), 1,4-butanesultone (purity $\geq 99 \%$, ref: B85501) and sulfuric acid (95.0-97.0\%, ref: 30743) were used to synthesize the Brønsted acidic IL used in the hydrothermal conversion of recovered cellulose to levulinic acid. Methyl isobutyl ketone (MIBK) (purity $\geq 99.5 \%$, ref: 293261) was used to extract levulinic acid from Brønsted acidic ionic liquid after the process of conversion. Pure cellulose Sigmacell (ref: S3504) was used to realize comparative experiments of hydrothermal liquefaction. Glucose (purity $\geq 99.5 \%$, ref: 49139), levulinic acid (98 wt.\%, ref: L2009), 5-hydroxymethylfurfural (purity $\geq 98.0 \%$, ref: 53407), formic acid (purity $\geq 98 \%$, ref: 33015-M), DL-lactic acid (purity 90\%, ref: 69785) and furfural (purity 99\%, ref: 185914) were used to prepare calibration curves for high-performance liquid chromatography (HPLC).

\subsection{Sludge Collection and Managing}

Cellulose was extracted from two types of sludge: municipal primary sludge and paper industry sludge. The primary sludge (96\% water content) was collected after partial gravity thickening of the Wastewater Treatment Plant (WWTP), located in Reus, Spain. The industrial dehydrated sludge (53\% water content) was provided by the paper international company Gomà-Camps, S.A., La Riba, Tarragona, Spain. After collection, both types of sludge were stored in a fridge at $4{ }^{\circ} \mathrm{C}$ and were used for characterization as received. Prior recovering of cellulose, both sludge were dried in an oven at $105^{\circ} \mathrm{C}$ during $48 \mathrm{~h}$. Then, they were directly used for the rest of the procedures.

\subsection{Sludge Characterization}

A full characterization of each sludge was realized in triplicate. Determination of total solids (TS), volatile solids (VS), and content of ash, proteins, lipids and carbohydrates were proceeded by conventional methods mentioned in previous studies [22,25].

Total solids (TS) of each sludge were determined by the standard method 2540 B [32]. Wet primary sludge and dried paper industry sludge with known quantity (between 0.5 to 2.0 g) were placed in a 
previously weighted ceramic capsule and then they were put in the oven at $105^{\circ} \mathrm{C}$ for $24 \mathrm{~h}$. Total solids were calculated with the formula:

$$
\% \mathrm{TS}=\frac{(\text { Weight dry capsule plus dry sample } \mathrm{g}-\text { Weight dry capsule g) }}{\text { Weight sample as received } \mathrm{g}} \times 100
$$

Volatile solids (VS) and ash content were determined by the standard method $2540 \mathrm{E}$ [32]. The weighted dry capsule with dry sample was placed in the muffle at $550{ }^{\circ} \mathrm{C}$ for $1 \mathrm{~h}$. Ash and volatile solids were calculated with the formulas:

$$
\begin{gathered}
\% \text { Ash }=\frac{\left(\text { Weight of capsule and sample after } 550{ }^{\circ} \mathrm{C} \mathrm{g}-\text { Weight dry capsule } \mathrm{g}\right)}{(\text { Weight dry capsule plus dry sample } \mathrm{g}-\text { Weight dry capsule } \mathrm{g})} \times 100 \\
\% \mathrm{VS}=100-\% \text { Ash }
\end{gathered}
$$

Lipids content of each sludge was determined by the standard method $5520 \mathrm{E}$ [32]. There was $20 \mathrm{~g}$ of sample of each sludge acidified with $0.3 \mathrm{~mL}$ of $\mathrm{HCl}$. Then, $25 \mathrm{~g}$ of $\mathrm{MgSO}_{4} \cdot \mathrm{H}_{2} \mathrm{O}$ was added in order to dewater acidified samples of sludge. The samples were mixed and then, they were crushed until they became a fine powder. Then, the samples were transferred into the cellulose Soxhlet extraction thimble and covered with a glass wool. The extraction was done in a Soxhlet extractor using hexane as a solvent at a velocity of 20 cycles/hour for $4 \mathrm{~h}$. After all, the hexane was evaporated through a rotary evaporation. The lipids were kept in a desiccator overnight to remove remained traces of hexane and weighed the next day. The flasks were measured before and after the experiment. Mass of lipids was calculated by weighing and with the formula:

$$
\% \text { Lipids }=\frac{(\text { Weight Lipids }+ \text { flask } g-\text { Weight of flask } \mathrm{g})}{\text { Weight of TS } \mathrm{g}} \times 100
$$

Proteins content of each sludge was determined by the Lowry method using Folin phenol reagent [33]. Firstly, the calibration curve of $0.5 \mathrm{~g}$ Bovine serum albumin/L patron was prepared. Then, diluted samples of each sludge were heated with $2 \mathrm{M}$ solution of $\mathrm{NaOH}$ in order to dissolve proteins. The absorbance of patron as well as sludge samples were measured at $750 \mathrm{~nm}$. The amount of proteins was calculated by the colorimetric method.

Carbohydrates determination was carried out based on phenol sulfuric method of Dubois [34]. Calibration curve of $0.1 \mathrm{~g}$ glucose/L was prepared as a patron. Diluted samples of each sludge were mixed with phenol solution and then with concentrated sulfuric acid. The absorbance of patron as well as sludge samples were measured at $480 \mathrm{~nm}$. The amount of carbohydrates was calculated by the colorimetric method.

\subsection{Recovery of Cellulose from Sludge}

The recovery of cellulose from both types of sludge was carried out using the method described in previous studies [22-24], with small modifications. Briefly, instead of wet sludge, dry sludge (DS) was used. This was necessary to prepare a big batch of recovered cellulose. The use of wet sludge ( $96 \%$ or $53 \%$ water content) would require working with too big volumes of sludge and ionic liquid. Dried sludge was placed in a round bottom flask and Tetrakis IL was added in ratio $1 \mathrm{~g}_{\mathrm{DS}}: 10 \mathrm{~mL}$. The mixture was stirred and heated to $100{ }^{\circ} \mathrm{C}$ with an oil bath maintained $24 \mathrm{~h}$. After this time, the oil bath was removed and the flask cooled down to ambient temperature. At that point, $10 \mathrm{~mL}$ of water for each gram of dry sludge were added to the solubilized cellulose. The rest of the procedure was the same as in the previous studies. After reaction, IL was recovered by water evaporation in a rotary evaporator at $80^{\circ} \mathrm{C}$ and $300 \mathrm{mbar}$. Then, IL was ready to be reused for other successive recovering. 


\subsection{Characterization of Recovered Cellulose}

The cellulose was analyzed to determine the volatile solid and ash content according to standard method $2540 \mathrm{E}$ [32]. The amount of proteins was calculated as a difference between proteins in sludge as received and proteins determined in ionic liquid phase by Lowry method [33]. Cellulose, hemicellulose and lignin were analyzed by high performance liquid chromatography (HPLC) after strong hydrolysis following method presented elsewhere [24].

\subsection{Bleaching of Recovered Cellulose}

Bleaching method was carried out according to literature [26]. Dried recovered cellulose from both sludge was placed in a round bottom flask. Then, $250 \mathrm{~mL}$ of freshly prepared $8 \% \mathrm{H}_{2} \mathrm{O}_{2}(v / v)$ was added. The mixture was kept under agitation at room temperature during $24 \mathrm{~h}$. After that, $\mathrm{H}_{2} \mathrm{O}_{2}$ and solids were separated by centrifugation ( $8000 \mathrm{rpm}, 5 \mathrm{~min}$ ). $\mathrm{H}_{2} \mathrm{O}_{2}$ was kept in order to determine the content of proteins by Lowry method [33] and, the ash content by the conventional method $2540 \mathrm{E}$ [32]. On the other side, the solid was washed with distilled water and centrifuged ( $8000 \mathrm{rpm}, 5 \mathrm{~min}$ ). Then, the solid was hydrolyzed with $250 \mathrm{~mL}$ of $0.1 \mathrm{~N} \mathrm{HCl}$ in an ultrasonic bath (Bandelin Electronic DT $514 \mathrm{H}$, Berlin, Germany) at a temperature of $60 \pm 1^{\circ} \mathrm{C}$ for $5 \mathrm{~h}$. Afterward, the liquid was removed by centrifugation $(8000 \mathrm{rpm}, 5 \mathrm{~min}$ ) and the solid was washed several times with distilled water until neutralization of the washing liquid of the solid. At the end, the solid was dried overnight in the oven at $105^{\circ} \mathrm{C}$ and analyzed for ash, proteins, cellulose, hemicellulose and lignin content as it was described before. Additionally, purified cellulose was characterized by Fourier Transform Infrared (FTIR) spectroscopy. The samples, without any further preparation, were scanned using a Fourier Jasco FT/IR-600 Plus spectrometer (Barcelona, Spain) with a diamond golden gate ATR reflectance cell.

\subsection{Synthesis of the Brønsted Acidic Ionic Liquid}

The Brønsted acidic ionic liquid 4-(3-methylimidazolium) butanesulfonic acid hydrogenosulfate [mimC $\left.\mathrm{SO}_{3} \mathrm{H}\right]\left[\mathrm{HSO}_{4}\right]$ was prepared according to literature [25]. Briefly, equimolar quantities of 1-methylimidazole and 1,4-butanesultone were added to a round bottom flask fitted with a condenser and stirred at $80^{\circ} \mathrm{C}$ for $10 \mathrm{~h}$ under nitrogen purge. Then, the obtained solid was washed with toluene and diethyl ether and, dried under vacuum overnight. A stoichiometric amount of acid $\mathrm{H}_{2} \mathrm{SO}_{4}$ was added dropwise to the white solid and stirred overnight at $60^{\circ} \mathrm{C}$ under reflux condenser and nitrogen purge. The obtained viscous IL was dried under vacuum and characterized by ${ }^{1} \mathrm{H}$ NMR spectroscopy (Varian NMR System 400, Palo Alto, CA, USA).

The IL was characterized by ${ }^{1} \mathrm{H}$ NMR spectroscopy, to confirm its structure. ${ }^{1} \mathrm{H}$ NMR spectrum (400 MHz, d $\mathrm{d}^{4}$-methanol), $\delta(\mathrm{ppm}): 1.79\left(\mathrm{p}, 2 \mathrm{H}, \mathrm{CH}_{2}, \mathrm{~J}=7.2\right), 2.05\left(\mathrm{p}, 2 \mathrm{H}, \mathrm{CH}_{2}, \mathrm{~J}=7.6\right), 2.9(\mathrm{t}, 2 \mathrm{H}$, $\left.\mathrm{CH}_{2}-\mathrm{SO} 3 \mathrm{H}, \mathrm{J}=7.6\right), 3.94\left(\mathrm{~s}, 3 \mathrm{H}, \mathrm{N}-\mathrm{CH}_{3}\right), 4.27\left(\mathrm{t}, 2 \mathrm{H}, \mathrm{N}-\mathrm{CH}_{2}, \mathrm{~J}=7.2\right), 7.59(\mathrm{t}, 1 \mathrm{H}, \mathrm{CH}, \mathrm{J}=1.2), 7.66(\mathrm{t}, 1 \mathrm{H}$, $\mathrm{CH}, \mathrm{J}=1.6), 8.96(\mathrm{~s}, 1 \mathrm{H}, \mathrm{N}-\mathrm{CH}-\mathrm{N})$.

\subsection{Conversion of Purified Cellulose to Levulinic Acid}

\subsubsection{Reaction Experimental Procedure}

The procedure of conversion of cellulose to levulinic acid, presented in Figure 1, is based on a recent work [3]. Different amounts of purified cellulose (2.2 to $16.0 \mathrm{~g})$, Brønsted acidic ionic liquid (26.0-36.0 g) and $180 \mathrm{~mL}$ of distilled water were utilized. The substances were introduced in a $1 \mathrm{~L}$ stainless steel autoclave (Autoclave Engineers model EZE Seal) with heating shell and MagneDrive ${ }^{\circledR}$ stirrer (magnetically coupled, packless rotary impeller system). The amounts of purified cellulose and IL were chosen based on the best conditions described in the work of Ren et al., 2015 [3]. Two last experiments were carried out with wet primary sludge as received ( $96 \%$ water content) and paper industry sludge as received ( $53 \%$ water content). These two experiments, considered as blank assays, allow the comparison of performances with the other experiments realized with bleached sludge. After closing the reactor, the temperature was settled up to $170^{\circ} \mathrm{C}$. The reactor took $\sim 30 \mathrm{~min}$ to reach 
the desired temperature. The pressure in the reactor at that temperature was over 7 bars and was constant during all the reaction time. Two different times of reaction were used after reaching the process temperature: 2 and $5 \mathrm{~h}$. After the reaction, the heating shell was removed and the system was cooled in cold water. The cooling time was $\sim 35 \mathrm{~min}$. After cooling, the reactor went back to atmospheric pressure.

\subsubsection{Cleaning of the Reactor and Separation of Products}

After opening of the reactor, the content was poured into a beaker and the reactor interior itself was cleaned with deionized water to recover all products: a black mixture of insoluble solids and liquid. Then, the dark brown insoluble solids, also called humins [3,13], were separated from the liquid phase by filtration with a Büchner funnel. The solids were washed with water several times. Then, they were oven dried at $105{ }^{\circ} \mathrm{C}$ for $24 \mathrm{~h}$ and weighed. The yield of insoluble solids (\%) was calculated with the initial weight of biomass used in the process. Furthermore, the solids were characterized by FTIR spectroscopy.

The liquid phase, mixture of water, IL and products, was left overnight in the oven at $105^{\circ} \mathrm{C}$ to evaporate the water. Then, the organic products were solubilized with methyl isobutyl ketone (MIBK) and separated from the ionic liquid by centrifugation at $8000 \mathrm{rpm}$ for $5 \mathrm{~min}$. The formation of two phases, MIBK and products (upper layer) and ionic liquid (down layer), allowed an easily separation of products from the ionic liquid. The upper layer was gathered and then, MIBK was evaporated at the rotary evaporator at $85^{\circ} \mathrm{C}$ and 250 mbar. At that point, products were dried under vacuum and weighted. Products were characterized by HPLC (Agilent Technologies 1100 Series HPLC System, Barcelona, Spain). For this, they were dissolved in water and analyzed by HPLC equipped with a Refractive Index Detector (RID) and a Hi-Plex H column $(300 \times 7.7 \mathrm{~mm})$, filled by a robust sulfonated cross-linked styrene-divinylbenzene gel in hydrogen form. Chromatograph conditions were as follow: injection volume $20.0 \mu \mathrm{L}$, mobile phase $0.005 \mathrm{M} \mathrm{H}_{2} \mathrm{SO}_{4}$, flow rate $0.7 \mathrm{~mL} / \mathrm{min}$, column temperature $60^{\circ} \mathrm{C}$, RID temperature $55^{\circ} \mathrm{C}$. The concentration of each compound was determined using calibration curves obtained with standard solutions with known concentrations. The yield of levulinic acid (\%) was calculated from the initial weight of cellulose used in the reaction. Additionally, products were analyzed by LC-MS with an Agilent 1200 liquid chromatograph, coupled to a 6210 Time of Flight (TOF) mass spectrometer (Agilent Technologies, Waldbronn, Germany) and with an electrospray ionization (ESI) interface. Experiments were performed using a Hi-Plex $\mathrm{H}$ column $(300 \times 7.7 \mathrm{~mm})$ provided by Agilent Technologies under isocratic conditions $\left(\mathrm{H}_{2} \mathrm{O}+0.1 \% \mathrm{HCOOH}\right)$ and a constant flow of $0.7 \mathrm{~mL} / \mathrm{min}$. The HPLC eluate was directly pumped into ESI interface without flow splitting. The ESI conditions were as follow: gas temperature $300{ }^{\circ} \mathrm{C}$, drying gas $12 \mathrm{~L} / \mathrm{min}$, nebulizer $40 \mathrm{psi}$, fragmentor $120 \mathrm{~V}$, capillary voltage (3000 V), and mass range 50-1200.

\section{Conclusions}

The process of production of levulinic acid from municipal or paper industry sludges has allowed to obtain very interesting results: (i) the Tetrakis (hydroxymethyl) phosphonium chloride ionic liquid allows the extraction of all the cellulose in both sludges, however, the precipitated cellulose still contains proteins and ashes; (ii) the bleaching process by hydrogen peroxide and hydrochloric acid does not work as well as expected, after the process the cellulose continues to have impurities that will be annoying in the reaction; (iii) catalyzed hydrothermal liquefaction of cellulose is a process that makes it possible to produce levulinic acid, but the operating conditions have to be optimized; and (iv) it is possible to carry out an integrated process for the production of levulinic acid from residual biomass, in this case of sludge from municipal or industrial treatment plants. Finally, it should be noted that the obtained conversions to levulinic acid are not high, up to $31 \%$ with industrial sludge and up to $25 \%$ with municipal sludge. However, it must be emphasized that the entire project is a technological feasibility study. The use of waste from wastewater treatment plants can lead to an 
increase in their income when it is well known that the cost of disposal their wastes is the biggest part of their operational costs.

Author Contributions: Conceptualization, C.B.; Data curation, J.G. and C.B.; Funding acquisition, J.G. and C.B.; Investigation, K.G. and C.L.; Methodology, K.G., E.T., and C.B.; Project administration, J.G.; Resources, J.G. and C.B.; Supervision, C.B.; Validation, E.T. and C.B.; Visualization, K.G. and C.B.; Writing-original draft, K.G. and C.L.; Writing-review \& editing, K.G., E.T., and C.B. All authors have read and agreed to the published version of the manuscript.

Funding: This research was funded by Universitat Rovira i Virgili (2017PFR-URV-B2-33 and 2016PMF-PIPF-29), Spanish Ministerio de Economía y Competitividad and the FEDER grant (CTM2015-67970).

Acknowledgments: The authors wish to acknowledge the public company Gestió Ambientali Abstament S.A. (WWTP of Reus, Spain) and the company Gomà-Camps, S.A. (La Riba, Tarragona, Spain) for their kind collaboration during this project. Katarzyna Glińska thanks for the Martí Franquès pre-doctoral scholarship provided by the Universitat Rovira i Virgili. The authors are recognized by the Comissionat per a Universitats i Recerca del DIUE de la Generalitat de Catalunya (2017-SGR-396).

Conflicts of Interest: The authors declare no conflict of interest.

\section{References}

1. Xiong, X.; Yu, I.K.M.; Tsang, D.C.W.; Bolan, N.S.; Ok, Y.S.; Igalavithanan, A.D.; Kirkham, M.B.; Kim, K.H.; Vikrant, K. Value-added chemicals from food supply chain wastes: A critical review. Chem. Eng. J. 2019, 375, 121983. [CrossRef]

2. Liu, S.; Wang, K.; Yu, H.; Li, B.; Yu, S. Catalytic preparation of levulinic acid from cellobiose via Brønsted-Lewis acidic ionic liquids functional catalysts. Sci. Rep. 2019, 9, 1810. [CrossRef]

3. Ren, H.; Girisuta, B.; Zhou, Y.; Liu, L. Selective and recyclable depolymerization of cellulose to levulinic acid catalysed by acidic ionic liquid. Carbohyd. Polym. 2015, 117, 569-576. [CrossRef] [PubMed]

4. Elumalai, S.; Agarwal, B.; Sangwan, R.S. Thermo-chemical pretreatment of rice straw for further processing for levulinic acid production. Biores. Technol. 2016, 98, 1448-1453. [CrossRef] [PubMed]

5. Yu, I.K.M.; Tsang, D.C.W. Conversion of biomass to hydroxymethylfurfural: A review of catalytic systems and underlying mechanisms. Biores. Technol. 2017, 238, 716-732. [CrossRef] [PubMed]

6. Cao, L.; Yu, I.K.M.; Liu, Y.; Ruan, X.; Tsang, D.C.W.; Hunt, A.J.; Ok, Y.S.; Song, H.; Zhang, S. Lignin valorization for the production of renewable chemicals: State-of-the-art review and future prospects. Biores. Technol. 2018, 269, 465-475. [CrossRef] [PubMed]

7. Yang, F.; Fu, J.; Mo, J.; Lu, X. Synergy of Lewis and Brønsted acids on catalytic hydrothermal decomposition of hexose to levulinic acid. Energy Fuel 2013, 27, 6973-6978. [CrossRef]

8. Zhi, Z.; Li, N.; Qiao, Y.; Zheng, X.; Wang, H.; Lu, X. Kinetic study of levulinic acid production from corn stalk at relatively high temperature using $\mathrm{FeCl}_{3}$ as catalyst: A simplified model evaluated. Ind. Crop. Prod. 2015, 76, 672-680. [CrossRef]

9. Sun, Z.; Xue, L.; Wang, S.; Wang, X.; Shi, J. Single step conversion of cellulose to levulinic acid using temperature-responsive dodeca-aluminotungstic acid catalysts. Green Chem. 2016, 18, 742-752. [CrossRef]

10. Kumar, K.; Pathak, S.; Upadhyayula, S. 2nd generation biomass derived glucose conversion to 5-hydroxymethulfurfural and levulinic acid catalyzed by ionic liquid and transition metal sulfate: Elucidation of kinetics and mechanism. J. Clean. Prod. 2020, 256, 120292. [CrossRef]

11. Kumar, K.; Parveen, F.; Patra, T.; Upadhyayula, S. Hydrothermal conversion of glucose to levulinic acid using multifunctional ionic liquids: Effect of metal ion cocatalysts on the product yield. New J. Chem. 2018, 42, 228-236. [CrossRef]

12. Matsagar, B.M.; Dhepe, P.L. Effect of cations, anions and $\mathrm{H}^{+}$concentration of acidic ionic liquids on valorization of polysaccharides into furfural. New J. Chem. 2017, 41, 6137-6144. [CrossRef]

13. Badgujar, K.C.; Wilson, L.D.; Bhanage, B.M. Recent advances for sustainable production of levulinic acid in ionic liquids from biomass: Current scenario, opportunities and challenges. Renew. Sust. Energ. Rev. 2019, 102, 266-284. [CrossRef]

14. Velaga, B.; Parde, R.P.; Soni, J.; Peela, N.R. Synthesized hierarchical mordenite zeolites for the biomass conversion to levulinic acid and the mechanistic insights into humins formation. Micropor. Mesopor. Mat. 2019, 287, 18-28. [CrossRef] 
15. Rasmussen, H.; Sørensen, H.R.; Meyer, A.S. Formation of degradation compounds from lignocellulosic biomass in the biorefinery: Sugar reaction mechanisms. Carbohydr. Res. 2014, 385, 45-57. [CrossRef] [PubMed]

16. Mija, A.; van der Waal, J.C.; Pin, J.M.; Guigo, N.; de Jong, E. Humins as promising material for producing sustainable carbohydrate-derived building materials. Constr. Build. Mater. 2017, 139, 594-601. [CrossRef]

17. Kang, S.; Fu, J.; Zhang, G. From lignocellulosic biomass to levulinic acid: A review on acid catalysed hydrolysis. Renew. Sustain. Energ. Rev. 2018, 94, 340-362. [CrossRef]

18. Girisuta, B.; Janssen, L.P.B.M.; Heeres, H.J. Kinetic study on the acid-catalyzed hydrolysis of cellulose to levulinic acid. Ind. Eng. Chem. Res. 2007, 46, 1696-1708. [CrossRef]

19. Gürbüz, E.I.; Gallo, J.M.R.; Alonso, D.M.; Wettstein, S.G.; Lim, W.Y.; Dumesic, J.A. Conversion of hemicellulose into furfural using solid acid catalyst in $\gamma$-valerolactone. Angew. Chem. Int. Ed. 2013, 52, 1270-1274. [CrossRef]

20. Galletti, A.M.R.; Antonetti, C.; De Luise, V.; Licursi, D.; Di Nasso, N.N.O. Levulinic acid production from waste biomass. BioResources 2012, 7, 1824-1834.

21. Lappalainen, K.; Kuorikoski, E.; Vanvyve, E.; Dong, Y.; Kärkkäinen, J.; Niemelä, M.; Lassi, U. Brőnsted and Lewis acid catalyzed conversion of pulp industry waste biomass to levulinic acid. BioResources 2019, 14, 7025-7040.

22. Olkiewicz, M.; Plechkova, N.V.; Fabregat, A.; Stüber, F.; Fortuny, A.; Font, J.; Bengoa, C. Efficient extraction of lipids from primary sewage sludge using ionic liquids for biodiesel production. Sep. Purif. Technol. 2015, 153, 118-125. [CrossRef]

23. Olkiewicz, M.; Caporgno, M.P.; Font, J.; Legrand, J.; Lepine, O.; Plechkova, N.V.; Pruvost, J.; Seddon, K.R.; Bengoa, C. A novel recovery process for lipids from microalgae for biodiesel production using a hydratedphosphonium ionic liquid. Green Chem. 2015, 17, 2813-2824. [CrossRef]

24. Glińska, K.; Ismail, M.; Goma-Camps, J.; Valencia, P.; Stüber, F.; Giralt, J.; Fabregat, A.; Torrens, E.; Olkiewicz, M.; Bengoa, C. Recovery and characterization of cellulose from industrial paper mill sludge using tetrakis and imidazolium based ionic liquids. Ind. Crop. Prod. 2019, 139, 111556. [CrossRef]

25. Olkiewicz, M.; Plechkova, N.V.; Earle, M.; Fabregat, A.; Stüber, F.; Fortuny, A.; Font, J.; Bengoa, C. Biodiesel production from sewage sludge lipids catalysed by Brønsted acidic ionic liquids. Appl. Catal. B Environ. 2016, 18, 738-746. [CrossRef]

26. Ahuja, D.; Kaushik, A.; Singh, M. Simultaneous extraction of lignin and cellulose nanofibrils from waste jute bags using one post-treatment. Int. J. Biol. Macromol. 2018, 107, 1294-1301. [CrossRef]

27. Wu, Y.; Wu, J.; Yang, F.; Tang, C.; Huang, Q. Effect of $\mathrm{H} 2 \mathrm{O} 2$ bleaching treatment on the properties of finished transparent wood. Polymers 2019, 11, 776. [CrossRef]

28. Lin, N.; Zhu, W.; Fan, X.; Wang, C.; Chen, C.; Zhang, H.; Chen, L.; Wu, S.; Cui, Y. Key factor on improving secondary advanced dewatering performance of municipal dewatered sludge: Selective oxidative decomposition of polysaccharides. Chemosphere 2020, 249, 126108. [CrossRef]

29. Sambusti, C.; Monlau, F.; Barakat, A. Bioethanol fermentation as alternative valorisation route of agricultural digestate according to a biorefinery approach. Biores. Technol. 2016, 212, 289-295. [CrossRef]

30. Li, S.; Deng, W.; Wang, S.; Wang, P.; An, D.; Li, Y.; Zhang, Q.; Wang, Y. Catalytic transformation of cellulose and its derivatives into functionalized organic acids. ChemSusChem 2018, 11, 1995-2028. [CrossRef]

31. Kumar, S.; Ahluwalia, V.; Kundu, P.; Sangwan, R.S.; Kansal, S.K.; Runge, T.M.; Elumalai, S. Improved levulinic acid production from agri-residue biomass in biphasic solvent system through synergistic catalytic effect of acid and products. Biores. Technol. 2018, 251, 143-150. [CrossRef] [PubMed]

32. Rice, E.W.; Baird, R.B.; Eaton, A.D.; Clesceri, L.S. Standard Methods for the Examination of Water and Wastewater, 22nd ed.; APHA AWWA WEF: Washington, DC, USA, 2012.

33. Lowry, O.H.; Rosebrough, N.J.; Farr, A.L.; Randall, R.J. Protein measurement with the Folin phenol reagent. J. Biol. Chem. 1951, 193, 265-275. [PubMed]

34. Dubois, M.; Gilles, K.A.; Hamilton, J.K.; Rebers, P.A.; Smith, F. Colorimetric method for determination of sugars and related substances. Anal. Chem. 1956, 28, 350-356. [CrossRef]

(C) 2020 by the authors. Licensee MDPI, Basel, Switzerland. This article is an open access article distributed under the terms and conditions of the Creative Commons Attribution (CC BY) license (http://creativecommons.org/licenses/by/4.0/). 